\title{
Faktor-Faktor yang Memengaruhi Jumlah Korban Meninggal Akibat Banjir dengan Pendekatan Model Zero Inflated Poisson
}

\author{
Novia Permatasari, ${ }^{1,}$ a), Nashir Wahyudi ${ }^{1, b)}$ \\ ${ }^{1}$ Badan Pusat Statistik Republik Indonesia, Jalan Dr. Soetomo 6-8 Jakarta. \\ E-mail: a)noviaprmatasari@gmail.com, ${ }^{\text {b)}}$ nashirwahyudi@gmail.com
}

\begin{abstract}
Flood is natural disaster with a higher total incidence and mortality of other hydrometeorological natural disaster in Indonesia. There are many factors that influence the number of deaths due to flood, one of which is the welfare of the community. This study aims to implement Zero Inflated Model to identify factors of community welfare that affect disaster victims due to flood in Indonesia in 2020 . Using zero inflated poisson method, we can solve the overdispersion problem due to too inflated zeros on dependent variable, along with the magnitude of community welfare variable influence on the number of victims due to flood. Community welfare factors consist of demographic and surrounding environment. Based on the results, it is known that based on demographics characteristics, there are two factors that influence the number of flood victims, i.e population who are married and population of women. Meanwhile, for the environmental group around the victim, the influencing factors are floor condition, morbidity rate, dependency rate, and per capita income.
\end{abstract}

Keywords: flood, victim, zero inflated poisson, overdispersion.

\begin{abstract}
Abstrak
Bencana banjir merupakan bencana alam dengan total kejadian serta kematian yang lebih tinggi dibanding bencana alam hidrometeorologi lainnya di Indonesia. Terdapat banyak faktor yang memengaruhi jumlah kematian akibat banjir, salah satunya adalah tingkat kesejahteraan masyarakat. Penelitian ini bertujuan untuk mengimplementasikan metode Zero Inflated Poisson guna mengetahui faktor-faktor kesejahteraan masyarakat yang memengaruhi jumlah korban meninggal akibat banjir di Indonesia tahun 2020. Dengan menggunakan metode zero-inflated poisson, kita dapat mengatasi masalah overdispersi akibat terlalu banyak nilai nol pada variabel dependen, serta mengetahui seberapa besar pengaruh variabel kesejahteraan masyarakat terhadap jumlah korban meninggal akibat banjir. Faktor kesejahteraan masyarakat tersebut terdiri atas karakteristik demografi dan lingkungan sekitar. Berdasarkan hasil, diketahui bahwa untuk kelompok karakteristik demografi, faktor-faktor yang berpengaruh terhadap jumlah korban banjir adalah proporsi penduduk berstatus menikah dan proporsi penduduk perempuan. Sedangkan, untuk kelompok lingkungan sekitar korban, faktor-faktor yang berpengaruh adalah kondisi lantai, angka kesakitan, angka ketergantungan, dan pendapatan perkapita.
\end{abstract}

Kata-kata kunci: banjir, korban, zero inflated poisson, overdispersi. 


\section{PENDAHULUAN}

Indonesia merupakan wilayah yang rawan akan bencana alam. Pada tahun 2020, Badan Nasional Penanggulangan Bencana (BNPB) mencatat terdapat sebanyak 2925 kejadian bencana alam (Mashabi, 2020). Pada tahun tersebut, banjir menjadi bencana yang mendominasi dibandingkan bencana lainnya, yaitu $36,4 \%$ dari total bencana yang terjadi dengan total kejadian sebanyak 1065 kejadian. Diikuti oleh bencana tanah longsor dengan total kejadian sebanyak 572 atau 19,6\% dan $44 \%$ sisanya didominasi oleh bencana alam lainnya seperti kebakaran hutan dan gempa bumi. Tingginya kejadian banjir disebabkan adanya sebanyak 600 dari 5590 sungai induk yang berpotensi menyebabkan banjir di Indonesia, dengan total luas daerah rawan banjir sebesar 1,4 juta hektar (Nidejovi, 2020). Selain itu, iklim Indonesia yang bertipe tropis juga menjadi penyebab dari sering terjadinya bencana banjir, terutama pada daerah-daerah dengan dengan sistem drainase yang buruk. Salah satu contohnya adalah provinsi DKI Jakarta dimana fenomena banjir sudah menjadi rutinitas yang terjadi pada waktu-waktu tertentu.

Seperti bencana alam lainnya, bencana banjir mengakibatkan banyak kerugian. Selain kerugian ekonomi akibat kerusakan barang-barang elektronik dan terganggunya aktivitas distribusi, banjir juga dapat menyebabkan beberapa masalah kesehatan atau bahkan korban jiwa. Jumlah korban banjir di Indonesia sejak tahun 1990 hingga 2015 secara rata-rata tercatat 155 korban jiwa (Kesuma, et al., 2016). Pada tahun 2020, BNPB mencatat terdapat sebanyak 235 korban meninggal, 80 orang lebih banyak dibanding rata-rata korban jiwa periode 1990 hingga 2015. Menurut kepala pusat data, informasi, dan komunikasi BNPB Agus Wibowo dalam (Pebrianto, 2020) empat penyebab utama adanya korban meninggal pada saat kejadian banjir adalah terseret arus banjir, tertimbun longsor, tersengat listrik dan hipotermia. Hal ini mengisyaratkan bahwa kondisi lingkungan dan tempat tinggal dari korban memiliki peran penting dalam menjamin keselamatan dari korban pada saat banjir terjadi. Selain itu menurut (Diakakis, 2020), terdapat beberapa faktor yang berpengaruh terhadap ada tidaknya kematian pada saat bencana banjir, antara lain sebagai berikut: ciri-ciri demografis korban, yaitu karakteristik yang membedakan masyarakat berdasarkan faktor-faktor demografis seperti umur, jenis kelamin, pendidikan dsb; lingkungan sekitar berupa kondisi lingkungan dari tempat banjir terjadi seperti perkampungan atau perumahan; keadaan saat terjadi banjir menjelaskan keberadaan korban pada saat banjir terjadi misalnya korban sedang berada di luar atau di dalam ruangan; aktivitas korban pada saat terjadinya banjir; serta waktu terjadinya banjir. Diantara kelima faktor tersebut, faktor demografis dan kondisi lingkungan merupakan faktor yang dapat dihitung dan dikontrol secara agregat. Dengan mengontrol faktor-faktor tersebut, diharapkan dapat menurunkan jumlah korban meninggal akibat bencana banjir. Informasi berkaitan dengan kedua faktor tersbut tersedia pada data publikasi statistik kesejahteraan rakyat oleh Badan Pusat Statistik (BPS).

Penelitian mengenai jumlah kejadian dan korban dari bencana kebakaran sebelumnya pernah dilakukan oleh (Boadi, et al., 2015) dengan studi kasus wilayah negara Ghana. Sama seperti data korban banjir penelitian ini juga menggunakan data cacah sebagai variabel dependennya, sehingga (Boadi, et al., 2015) mengusulkan untuk menggunakan model negative binomial untuk mengatasi overdispersi pada model poisson-nya. Sama halnya dengan (Boadi, et al., 2015), (Siregar, 2019) juga melakukan analisis terhadap data berjenis cacah, yaitu kejadian kasus penyakit Tetanus Neonatarum di Jawa Timur. Pada penelitiannya model poisson (Siregar, 2019) juga mengalami overdispersi yang disebabkan oleh, kasus penyakit Tetanus Neonatarum adalah langka (rare case). Sehingga, alih-alih menggunakan model alternatif negatif binomial seperti (Boadi, et al., 2015), (Siregar, 2019) menerapkan model Zero-Inflated Poisson untuk mengatasi masalah overdispersi pada model poissonnya.

Lebih lanjut, penelitian mengenai kejadian bencana banjir dan jumlah korbannya pernah dilakukan oleh: (Ali, 2007) dan (Paul \& Mahmood, 2016). (Ali, 2007) menggunakan pendekatan kualitatif melalui wawancara terhadap korban guna mengetahui faktor-faktor apa saja yang memengaruhi kejadian banjir di Bangladesh. Sedangkan (Paul \& Mahmood, 2016) menggunakan regresi Poisson untuk melihat faktor-faktor yang memengaruhi kematian akibat banjir di Bangladesh tahun 19722003. Sayangnya, penelitian terkait faktor-faktor yang memengaruhi jumlah korban meninggal akibat 
banjir di Indonesia masih sangat terbatas. Hal ini tidak sebanding dengan banyaknya jumlah kejadian, serta korban yang diakibatkan oleh banjir di Indonesia.

Berdasarkan hal-hal di atas, penulis tertarik untuk mengetahui faktor-faktor yang memengaruhi jumlah korban meninggal akibat banjir di Indonesia tahun 2020. Pada penelitian ini, peneliti fokus pada faktor-faktor ciri demografis korban dan lingkungan sekitar, yang dapat digeneralisasikan sebagai tingkat kesejahteraan masyarakat.

\section{METODOLOGI}

\section{Bahan dan Data}

Data yang digunakan dalam penelitian ini adalah data bencana banjir di Indonesia tahun 2020 dari Badan Nasional Penanggulangan Bencana (BNPB) yang secara bebas dapat diakses melalui link https://gis.bnpb.go.id/. Sedangkan untuk variabel penjelas dalam penelitian ini menggunakan data publikasi Badan Pusat Statistik (BPS).

\section{Metode Penelitian}

Regresi poisson merupakan model regresi yang digunakan untuk analisis data cacah dan termasuk dalam generalized linear model dengan variabel dependen berdistribusi poisson dengan fungsi kepadatan peluang, yang tertulis dalam (Majore, et al., 2020):

$$
f\left(y_{i}, \mu_{i}\right)=\frac{\mu_{i}{ }^{y i} e^{-\mu i}}{y_{i} !}
$$

Dimana $y$ adalah peubah acak bernilai $0,1,2, \ldots$ dengan mean dan variance $\mu$. Dengan menggunakan fungsi link, model regresi poisson dapat dituliskan dalam bentuk sebagai berikut:

$$
\ln \left(\mu_{i}\right)=X_{i}^{T} \beta
$$

Regresi poisson mengharuskan terpenuhinya asumsi equidispersi, yaitu kesamaan nilai rata-rata dan varians variabel dependen. Sayangnya, kondisi tersebut sulit tercapai pada data riil. Kondisi ketika nilai varians lebih dari nilai rata-ratanya disebut overdispersi, sedangkan kondisi ketika nilai varians kurang dari rata-rata disebut underdispersi. Dibandingkan dengan keadaan underdispersi, overdispersi lebih sering terjadi (Zhu, 2012). Keadaan overdispersi dapat terjadi karena adanya nilai nol yang berlebihan, adanya outlier pada data, adanya autokorelasi, maupun kesalahan spesifikasi fungsi penghubung (Rahayu, 2020).

Asumsi equidispersi dapat dilihat dari nilai deviance dibagi dengan derajat bebas maupun nilai pearson chi-square dibagi dengan derajat bebas. Nilai yang lebih dari satu mengindikasikan adanya overdispersi, sedangkan nilai kurang dari satu mengindikasikan adanya underdispersi (Kusuma, et al., 2013). Model zero-inflated poisson merupakan model regresi dengan variabel dependen data cacah untuk mengatasi adanya overdispersi akibat terlalu banyak nilai nol. Pada model ZIP, variabel dependen dengan nilai 0 , yang dikenal dengan zero state, dan nilai lebih dari nol, yang dikenal dengan poisson state, variabel dependen dengan nilai 0 dan tidak diestimasi secara terpisah, dengan fungsi probabilitas sebagai berikut:

$$
f\left(y_{i}\right)= \begin{cases}\omega_{i}+\left(1-\omega_{i}\right) e^{-\mu i} & , \text { untuk } y_{i}=0 \\ \left(1-\omega_{i}\right) \frac{\mu_{i}{ }^{y i} e^{-\mu i}}{y_{i} !} & , \text { untuk } y_{i}>0\end{cases}
$$


Dengan $\omega$ merupakan peluang terjadinya zero state. Kedua fungsi probabilitas tersebut memenuhi model gabungan berikut:

$$
\begin{gathered}
\ln \left(\mu_{i}\right)=\boldsymbol{X}_{i}^{T} \boldsymbol{\beta} \\
\operatorname{logit}\left(\omega_{i}\right)=\boldsymbol{X}_{i}^{T} \boldsymbol{Y}
\end{gathered}
$$

Pemilihan variabel penjelas pada model dilakukan melalui dua tahap, yaitu melihat nilai korelasi dari setiap variabel terhadap jumlah korban banjir yang meninggal. Kemudian, dilanjutkan dengan backward selection pada variabel-variabel dengan korelasi tinggi. Peneliti juga memperhatikan adanya multikolinearitas, yaitu adanya korelasi yang kuat antar variabel penjelas.

Uji parameter pada model yang dihasilkan dilakukan secara simultan maupun parsial. Pengujian parameter secara simultan dilakukan menggunakan Uji Likelihood Ratio dengan hipotesis sebagai berikut:

$$
\begin{gathered}
\mathrm{H} 0: \beta_{1}=\cdots \beta_{k}=\gamma_{1}=\cdots=\gamma_{l}=0 \\
\mathrm{H} 1: \text { Paling sedikit ada satu } \beta_{i} \neq 0 \text { atau } \gamma_{i} \neq 0
\end{gathered}
$$

Pengujian parameter secara parsial dilakukan menggunakan Uji Wald dengan hipotesis sebagai berikut:

$$
\begin{array}{ll}
\mathrm{H} 0: \beta_{i}=0 & \mathrm{H} 1: \beta_{i} \neq 0 \\
\mathrm{H} 0: \gamma_{i}=0 & \mathrm{H} 1: \gamma_{i} \neq 0
\end{array}
$$

Salah satu metode pemilihan model terbaik dapat dilakukan dengan melihat membandingkan nilai AIC (Akaike's Information Criterion) dan BIC (Bayesian Information Criterion), dimana nilai AIC dan BIC yang lebih kecil menunjukkan model yang lebih baik, (Dewanti, et al., 2016). Kemudian, peneliti melakukan Uji Vuong untuk membandingkan model regresi zero-inflated poisson dengan model regresi poisson yang telah dibangun. Hipotesis null yang digunakan adalah model poisson layak digunakan, dengan hipotesis alternatif model zero-inflated poisson. Ketika uji Vuong menghasilka $p$ value signifikan, maka model regresi zero-inflated poisson lebih layak digunakan daripada model regresi poisson. Tingkat signifikansi yang digunakan pada penelitian ini adalah $10 \%$.

\section{HASIL DAN PEMBAHASAN}

Sebagai gambaran awal, berikut adalah visualisasi dan deskripsi statistik dari jumlah korban meninggal akibat banjir 34 provinsi di Indonesia.

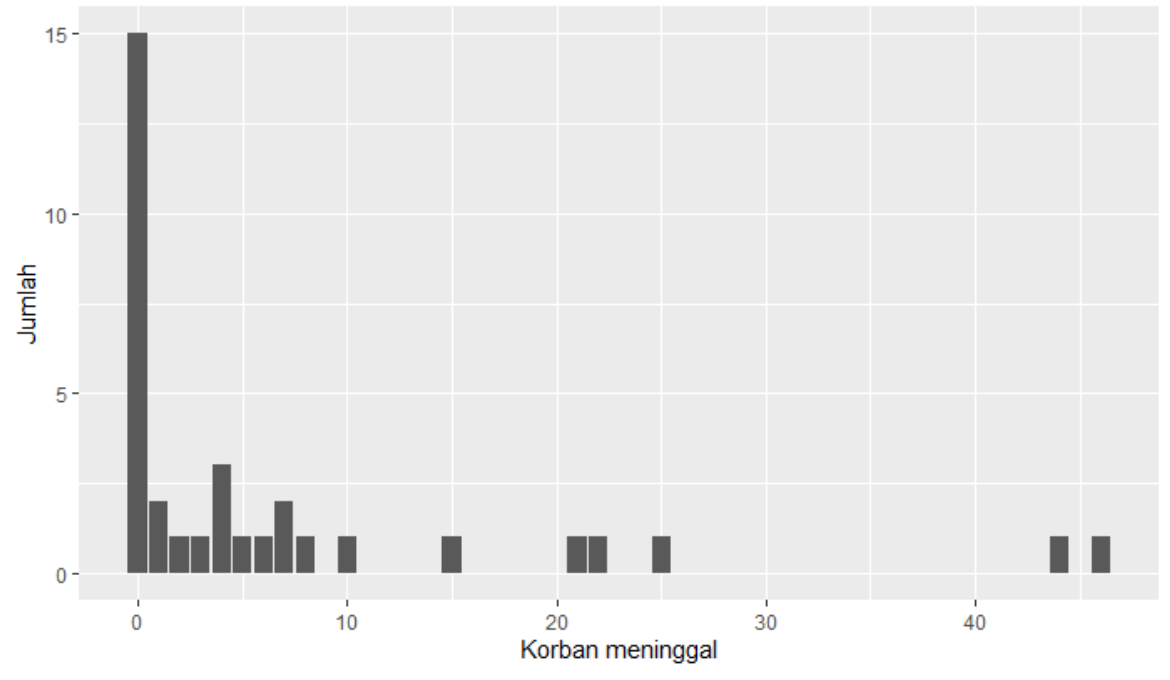

GAMBAR 1. Diagram batang jumlah korban meninggal 


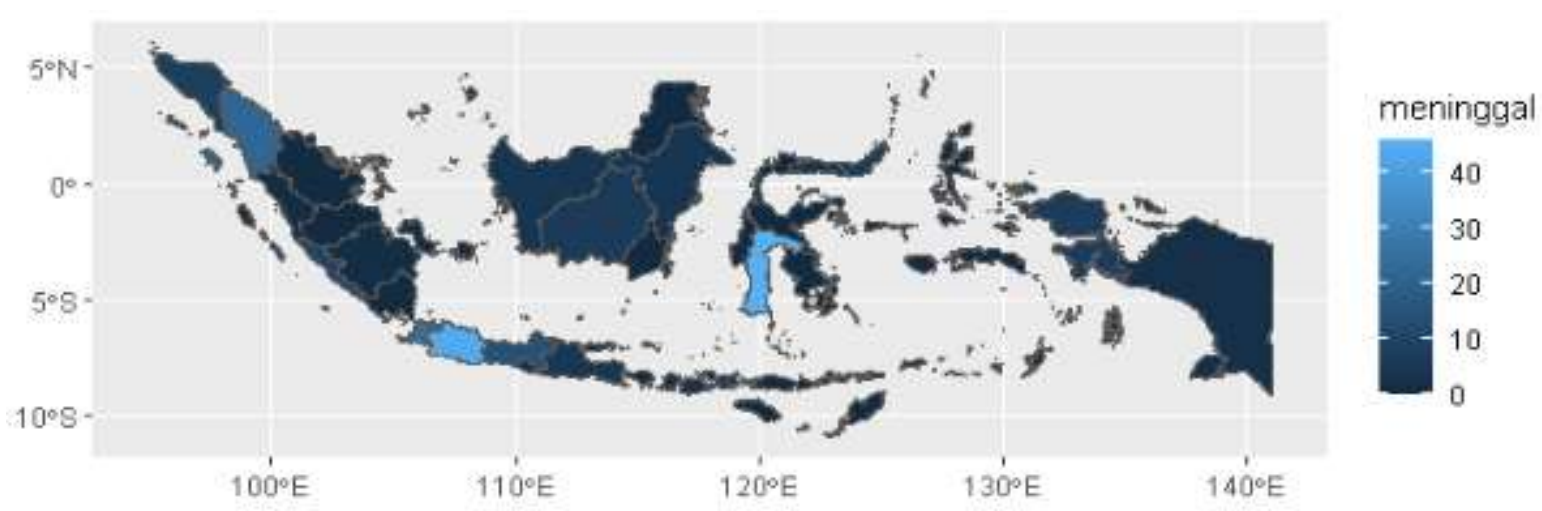

GAMBAR 2. Peta sebaran korban meninggal akibat banjir

Total kematian akibat banjir di Indonesia tahun 2020 sebanyak 235 jiwa, dengan kematian tertinggi berada di Provinsi Sulawesi Selatan sebanyak 46 jiwa dan Provinsi Jawa Barat sebanyak 44 jiwa. Berdasarkan GAMBAR 1, pada 15 dari 34 provinsi $(44,11 \%)$ di Indonesia tidak memiliki korban akibat bencana banjir atau bernilai nol. Adanya banyaknya nilai nol tersebut dapat menyebabkan asumsi equidispersi pada regresi poisson tidak dapat dipenuhi.

Untuk mengetahui besar pengaruh, dapat dibuat model dengan beberapa variabel penjelas yang didapatkan dari tahap pemilihan variabel sebelumnya seperti terlihat pada tabel di bawah ini.

TABEL 1. Variabel penjelas pada model terpilih

\begin{tabular}{cl}
\hline Variabel & \multicolumn{1}{c}{ Keterangan Variabel } \\
\hline X1 & Persentase penduduk perempuan \\
X2 & Angka ketergantungan \\
X3 & Persentase penduduk sudah menikah \\
X4 & Angka kesakitan \\
X5 & Pengeluaran penduduk per kapita (ribu rupiah) \\
X6 & Persentase rumah dengan lantai bukan tanah \\
\hline
\end{tabular}

Dengan menggunakan regresi poisson, didapatkan nilai deviance per derajat bebas sebesar 9,8151 sehingga terjadi overdispersi pada model yang dihasilkan. Maka dari itu, model poisson tidak layak digunakan. Untuk mengatasi masalah tersebut, dilakukan modelling dengan menggunakan model zeroinflated poisson, dan didapatkan estimasi parameter model regresi sebagai berikut: 
TABEL 2. Summary Model ZIP

\begin{tabular}{ccccc}
\hline Parameter & Estimasi & Standar error & Z - value & p-value \\
\hline Konstanta & 9,719463 & 6,417252 & 1,515 & 0,13 \\
$\boldsymbol{\beta 1}$ & $-0,71299$ & 0,117977 & $-6,043$ & $1,511 \mathrm{e}-11$ \\
$\boldsymbol{\beta 2}$ & 0,339488 & 0,037547 & 9,042 & $<2 \mathrm{e}-16$ \\
$\boldsymbol{\beta 3}$ & 0,288783 & 0,56667 & 5,096 & $3,47 \mathrm{e}-07$ \\
$\boldsymbol{\beta 4}$ & 0,211639 & 0,037176 & 5,693 & $1,25 \mathrm{e}-08$ \\
$\boldsymbol{\beta 5}$ & 0,052507 & 0,006635 & 7,913 & $2,50 \mathrm{e}-15$ \\
$\boldsymbol{\beta 6}$ & $-0,148161$ & 0,020413 & $-7,258$ & $3,93 \mathrm{e}-13$ \\
Konstanta & $-4,1516$ & 2,2022 & $-1,885$ & 0,0594 \\
$\mathbf{~} \mathbf{1}$ & 0,284 & 0,1572 & 1,806 & 0,0709 \\
\hline
\end{tabular}

Pada model zero-inflated poisson, dilakukan pengujian kesesuaian model menggunakan uji rasio likelihood. Pada model ZIP, didapatkan nilai LR sebesar -114 dengan p-value sebesar 5,291797e-21 Hasil tersebut menunjukkan bahwa model telah sesuai, dimana terdapat minimal satu variabel bebas yang berpengaruh terhadap variabel dependen.

Selanjutnya, dilakukan uji Wald untuk melihat signifikansi masing-masing parameter. Hasil uji parameter pada model regresi zero inflated poisson menunjukkan bahwa variabel persentase penduduk perempuan, angka ketergantungan, persentase penduduk sudah menikah, persentase penduduk tidak sekolah, angka kesakitan, pengeluaran per kapita, dan persentase rumah dengan lantai bukan tanah berpengaruh signifikan terhadap variabel respon. Variabel angka ketergantungan, persentase penduduk sudah menikah, angka kesakitan, dan pengeluaran per kapita menunjukkan pengaruh yang positif, sedangkan variabel persentase penduduk perempuan dan persentase rumah dengan lantai bukan tanah. Pada model logit, diperoleh variabel angka kesakitan berpengaruh signifikan terhadap variabel jumlah kematian akibat banjir dengan arah positif.

Hasil Vuong Test pada AIC-Corrected menunjukkan p-value sebesar 0,00034047, sedangkan pada BIC-Corerected sebesar 0,00039999. Hal ini ini menunjukkan bahwa model ZIP telah lebih baik dari model poisson yang didapatkan.

Berdasarkan uji signifikansi parameter di atas, diperoleh model regresi ZIP sebagai berikut:

$$
\begin{gathered}
\ln (\mu)=9,719463-0,71299 \times 1+0,339488 \times 2+0,288783 \times 3 \\
+0,211639 \times 4+0,052507 \times 5-0,148161 \times 6 \\
\operatorname{logit}(\omega)=-4,1516+0,284 X 4
\end{gathered}
$$

Model tersebut menunjukkan bahwa variabel yang memengaruhi keadaan bernilai nol dan poisson adalah berbeda. Model poisson menjelaskan bahwa:

- Setiap penambahan persentase penduduk perempuan sebesar satu persen maka rata-rata jumlah korban meninggal akibat banjir akan lebih kecil sebesar 0,49 kali dengan asumsi variabel lain konstan.

- Setiap penambahan angka ketergantungan sebesar satu satuan maka rata-rata jumlah korban meninggal akibat banjir akan lebih besar sebesar 1,40 kali dengan asumsi variabel lain konstan.

- Setiap penambahan persentase penduduk yang sudah menikah sebesar satu persen maka rata-rata jumlah korban meninggal akibat banjir akan lebih besar sebesar 1,33 kali dengan asumsi variabel lain konstan.

- Setiap penambahan angka kesakitan sebesar satu satuan maka rata-rata jumlah korban meninggal akibat banjir akan lebih kecil sebesar 1,24 kali dengan asumsi variabel lain konstan. 
- Setiap penambahan pengeluaran per kapita sebesar satu satuan (dalam ratusan ribu) maka rata-rata jumlah korban meninggal akibat banjir akan lebih besar sebesar 1,05 kali dengan asumsi variabel lain konstan.

- Setiap penambahan persentase hunian dengan jenis lantai bukan tanah maka rata-rata jumlah korban meninggal akibat banjir akan lebih kecil sebesar 0,86 kali dengan asumsi variabel lain konstan.

Model logit menjelaskan bahwa:

- Penambahan nilai sebesar $1 \%$ terhadap angka kesakitan di suatu provinsi akan meningkatkan risiko adanya korban meninggal sebesar 1,33 kali dengan asumsi variabel lainnya konstan.

Berdasarkan interpretasi di atas, diketahui bahwa semakin tinggi nilai pendapatan per kapita, maka semakin tinggi pula rata-rata jumlah korban meninggal akibat banjir pada provinsi tersebut. Hal ini kurang sesuai dengan teori/keadaan riil, dimana seharusnya provinsi dengan tingkat perekonomian yang lebih tinggi akan semakin mampu mengendalikan korban meninggal akibat banjir. Kondisi ini disebabkan oleh semakin tingginya pendapatan perkapita, akan semakin sedikit penduduk yang menjadi beban pembangunan daerah sehingga daerah dapat membangun infrastruktur umum menjadi lebih baik. Oleh karena itu, daerah tersebut akan lebih sigap dalam menerapkan langkah antisipasinya ketika bencana terjadi. Berdasarkan hal tersebut, peneliti menduga masih terdapat variabel-variabel lain diluar variabel kesejahteraan masyarakat yang mampu menjelaskan jumlah korban banjir. Peneliti mengusulkan pengembangan model dengan memasukkan variabel yang menggambarkan seberapa sering dan seberapa parah banjir tersebut terjadi.

\section{KESIMPULAN DAN SARAN}

Pada penelitian ini kami menggunakan model zero-inflated poisson untuk menganalisis data jumlah korban banjir di Indonesia pada tahun 2020 dengan variabel penjelas terbagi menjadi dua kelompok, yaitu karakteristik demografi dan kondisi lingkungan sekitar berdasarkan data Statistik Kesejahteraan Rakyat oleh BPS. Model ZIP dipilih karena pada umumnya korban bencana banjir hanya ada pada provinsi tertentu saja sehingga terdapat banyak nilai nol pada data penelitian. Hasilnya, untuk kelompok karakteristik demografi faktor-faktor yang berpengaruh jumlah terhadap jumlah korban banjir adalah persentase penduduk perempuan (X1) dan persentase penduduk berstatus menikah (X3). Sedangkan, untuk kelompok lingkungan sekitar korban faktor-faktor yang berpengaruh adalah angka ketergantungan (X2), angka kesakitan (X4), pengeluaran perkapita (X5), dan kondisi lantai (X6). Model ZIP yang diperoleh adalah sebagai berikut:

$$
\begin{gathered}
\ln (\mu)=9,719463-0,71299 \times 1+0,339488 \times 2+0,288783 \times 3 \\
+0,211639 \times 4+0,052507 \times 5-0,148161 \times 6 \\
\operatorname{logit}(\omega)=-4,1516+0,284 X 4
\end{gathered}
$$

Berdasarkan model yang didapatkan, diketahui bahwa variabel persentase penduduk perempuan, dan kondisi lantai bukan tanah berpengaruh negatif terhadap jumlah korban meninggal akibat banjir. Sedangkan variabel angka ketergantugan, persentase penduduk berstatus menikah, angka kesakitan, dan pengeluaran perkapita berpengaruh positif. 
Dengan demikian, berikut ini adalah beberapa langkah yang dapat dilakukan untuk menurunkan jumlah korban banjir:

1. Meningkatkan kesadaran masyarakat akan kebersihan dan kesehatan diri, serta ditunjang dengan fasilitas kesehatan dan layanan medis dengan standar yang baik bagi masyarakat guna menurunkan angka kesakitan masyarakat.

2. Memberikan sosialisasi dan wadah lapangan kerja agar pendapatan perkapita daerah tersebut bisa ditingkatkan, sedemikian sehingga semakin sedikit pula masyarakat yang menjadi beban dari pembangunan daerah tersebut.

\section{UCAPAN TERIMA KASIH}

Terima kasih penulis sampaikan kepada pihak Badan Nasional Penanggulangan Bencana dan Badan Pusat Statistik karena telah menyediakan data-data penelitian yang kami pakai pada penelitian ini.

\section{REFERENSI}

Ali, A. M. S., 2007. September 2004 Flood Event in Southwestern Bangladesh: A Study of its Nature, Cause, and Human Perception and Adjustments to a New Hazard. Natural Hazard, Volume 40, pp. $89-111$.

Boadi, C., Harvey, S. K. \& Gyeke-dako, A., 2015. Modelling of fire count data: fire disaster risk in Ghana. Springer Open Journal, Issue 4, pp. 1-17.

Dewanti, N. P. P., Susilawati, M. \& Srinadi, I. G. A. M., 2016. Perbandingan Regresi Zero Inflated Poisson (Studi Kasus: Angka Kematian Ibu di Provinsi Bali). e-Jurnal Matematika, 5(4), pp. 133138.

Diakakis, M., 2020. Types of Behavior of Flood Victims around Floodwaters. Correlation with Situational and Demographic Factors. Athens, Faculty of Geology and Geoenvironment, National and Kapodistrian University of Athens, pp. 1-17.

Kesuma, Z. M., Salwa, N., Rahayu, L. \& Jofipasi, C. A., 2016. Analisis Peramalan Bencana Banjir Di Indonesia: Studi Kasus Banjir Indonesia 1990-2015. Palembang, SEMIRATA Bidang MIPA 2016.

Kusuma, W., Komalasari, D. \& Hadijati, M., 2013. Model Regresi Zero Inflated Poisson Pada Data Overdispersion. Jurnal Matematika, 3(2), pp. 71-85.

Majore, M. M., Salaki , D. T. \& Prang, J. D., 2020. Penerapan Regresi Binomial Negatif Dalam Mengatasi Overdispersi Regresi Poisson Pada Kasus Jumlah Kematian Ibu. Jurnal Matematika dan Aplikasi, 9(2), pp. 133-139.

Mashabi, S., 2020. BNPB: Sepanjang 2020, Ada 2.925 Kejadian Bencana di Indonesia. [Online] Available at: https://nasional.kompas.com/read/2020/12/29/14190201/bnpb-sepanjang-2020-ada2925-kejadian-bencana-di-indonesia

[Diakses 24 April 2021].

Nidejovi, 2020. Pusat Penelitian Liminologi LIPI. [Online] Available at: $\quad$ http://www.limnologi.lipi.go.id/newsdetail.php?id=1039

[Diakses 4 maret 2021].

Paul, B. K. \& Mahmood, S., 2016. Selected physical parameters as determinants of flood fatalities in Bangladesh, 1972-2013. Natural Hazard, Volume 83, pp. 1703-1715.

Pebrianto, F., 2020. Empat Penyebab Korban Meninggal dalam Banjir Jabodetabek. [Online] Available at: https://nasional.tempo.co/read/1290512/empat-penyebab-korban-meninggal-dalambanjir-jabodetabek/full\&view $=$ ok

[Diakses 9 April 2021]. 
Rahayu, A., 2020. Model-Model Regresi untuk Mengatasi Masalah Overdipersi pada Regresi Poisson. Jurnal Peqguruang, 2(1), pp. 1-5.

Siregar, R. S. K., 2019. Pemodelan Regresi Zero Inflated Poisson (ZIP) dan Hurdle Model Pada Kasus Penyakit Tetanus Neonatorum. Euclid, Jurnal Pendidikan Matematika, 6(2), pp. 117-129.

Zhu, F., 2012. Modeling overdispersed or underdispersed count data with generalized Poisson integervalued GARCH models. Journal of Mathematical Analysis and Applications, 389(1), pp. 58-71. 